\title{
Thormation
}

Nordic Journal of Art and Research

ISSN: $1893-2479$

www.artandresearch.info

\section{Forming Life:}

\section{Aesthetic Awareness in Mental Health Care}

\author{
Arild Berg ${ }^{1}$, Boel Christensen-Scheel ${ }^{2}$, and Mette Holme Ingeberg ${ }^{3}$ \\ Oslo and Akershus University College of Applied Sciences
}

\begin{abstract}
Using cross-disciplinary perspectives from artistic research, aesthetic theory, and mental health care, this article discusses qualities in sensuous surroundings in mental health facilities. The background for the article is an increased awareness in aesthetic research concerning sensuous surroundings and their connection to health and well-being. However, this aesthetic awareness is only reflected to a small extent in research on mental health care surroundings. A further development of these perspectives is suggested in this article by introducing the concept of 'life form' from the art theorist Nicolas Bourriaud and the concepts of 'presentation' and 'perception' in theatrical communication from theatre researcher Willmar Sauter. These theories are discussed and exemplified on the basis of data from two mental health care wards: one from a psychogeriatric ward and the other from a polyclinic for eating disorders. Some essential qualities identified in the examples is that aesthetic environment and activity can be seen as formative to the inner state, and that different forms of sensuous activation and interaction could help patients escape communicative inhibition.
\end{abstract}

Keywords: Aesthetics, artistic research, empowerment, mental health care, participatory strategies, relational art.

\footnotetext{
${ }^{1}$ Department of Product Design, Faculty of Technology, Art and Design, arild.berg@ hioa.no

${ }^{2}$ Department of Art, Design and Drama, boel.christensen-scheel@hioa.no

${ }^{3}$ Department of Health, Nutrition and Management, Faculty of Health Sciences, metteh.ingeberg@senior.hioa.no

Oslo and Akershus University College of Applied Sciences, Postboks 4 St. Olavs plass, 0103 Oslo. 


\section{Research context}

The goal of this study was to introduce aesthetic perspectives and research into a mental health care discussion. Based on the sensuously oriented developments in recent art based research and aesthetic theory, we sought to identify potential areas of development through localizing and analyzing the use of the aesthetic elements in two psychiatric wards: the Psychogeriatric Ward at Akershus University Hospital (Skytta) (Ingeberg et al., 2012) and the Special Polyclinic for Eating Disorders at Oslo University Hospital (Gaustad) (Christensen-Scheel, 2013). More generally, the study seeks to address the dynamics of empowerment processes related to aesthetic strategies in health care situations. Therefore, the identification of phenomena relates to how empowerment processes can be affected when the atmosphere is changed or influenced by art and artistic practice. The research question has thus been to identify qualities concerning sensuous surroundings on different levels in mental health care and to discuss how these qualities can contribute to an increased aesthetic awareness in mental health care. The different levels of aesthetics that were considered include architecture, interior, art based therapy forms, and the possibilities for overall sensuous interaction with the environment offered to the patients. It is thus the environment itself, and the different possibilities for experience and interaction it contains, that has been of concern - inquiries into the patients' use and experience are not discussed to any degree.

The empirical material, which constitutes the foundation for the discussion in this article, was collected through two earlier studies: In the first mental health care context at the psychogeriatric ward at Skytta, the authors Mette Holme Ingeberg, psychiatric nurse and art and health researcher, and Arild Berg, applied art researcher and ceramic artist, had conducted a case study by collaborating with the staff in making and introducing ceramic art objects into a hospital environment, and further using them as a basis for art dialogues with patients (Ingeberg, Berg, et al., 2012). Artistic research was a part of this participatory art strategy (Varto, 2009). The data from Skytta was collected through participatory methods (Asaro, 2000; Varto, 2009; Yin, 2009), which were especially relevant because the participation created access to the field, a deeper understanding of artistic practice in the specific context, and the creation process could thus be documented from an insider perspective. Data were also collected by observation, interviews (Kvale \& Brinkmann, 2009), and focus group interviews (Wibek, 2010). These methods were chosen to provide qualitative data from different methodical sources and to enable triangulation of the findings.

The second mental health care context is the Special Polyclinic for Eating Disorders at Oslo University Hospital (Gaustad). The policlinic was chosen as material because it uses art therapy as its primary form of treatment, which is unique in Norway, but also rare in an international context. 
Interviews were conducted at the polyclinic with four therapists ${ }^{4}-$ three art therapists and one dietitian - the locations and therapy rooms were analyzed and photo documentation was made. No recordings were made of the actual use of the rooms by the patients. The analysis of the rooms and their use is based on observations of the rooms themselves, the way they were organized and equipped, and the therapists' renditions of their use, both while showing them and while talking about them in interviews. The therapists at Gaustad were interviewed through a semi-structured, qualitative interview (Kvale \& Brinkmann, 2009, p.23). They were asked questions such as: Can you talk about your relation to the rooms, the interior, and the art? What is your relation to aesthetics and the use of art in therapy? In addition, they were asked about their understandings about relations between inner and outer sensuousness, that is the relation between perceived environment and mental states. The selected data were categorized (Kvale \& Brinkmann, 2009) as qualities in relation to the initial criteria of sensuous surroundings and relations, life forms (Bourriaud, 2002, 2003), presentation, and perception (Sauter, 2000).

The wards under discussion are not seen as representative for mental health care in general but instead, they represent possible and exemplary ways of including aesthetic strategies in mental health care. Nevertheless, combining the experience from Skytta and Gaustad has given us a new point of view. The two studies together represented a unique combination that qualifies for a revelatory study of qualities related to sensuous environments in mental health care, as discussed by Robert Yin (Yin, 2009, p.48). The analysis of the phenomena itself has however been made with the help of art and theatre theory, as well as aesthetic philosophy. Because these concepts include relations as an essential part of the art, one of the study perspectives that could shed light on the data was from art philosopher Nicolas Bourriaud's conceptualizations of form and life form (2002, 2003). In addition, theatre and performance researcher Willmar Sauter's term of theatrical communication connects the art production, as material or text, to the perception and experience of art (Sauter, 2000), thus creating a relation between environment and mental state, between "inner" and "outer" landscapes.

This article aims for a pragmatic benefit of artistic experiences in an everyday context (Dewey, 1958), relational aesthetics in practice (Bourriaud, 2002), and enabling empowerment processes in mental health care (Rappaport, 1987; Tveiten et al., 2011). Therefore, this study aims to identify theory that is relevant for art didactic approaches. By identifying qualities and topics in practice, the findings will contribute to epistemological reflections in both art education (Varto, 2009) and art didactic, reflections that combine sensuous and art based knowledge with societal perspectives.

\footnotetext{
${ }^{4}$ Bjørg Standerholen (Oslo, March 29, 2009), Kari Rød (Oslo, May 24, 2012), Gunilla Forsberg (Oslo, May 24, 2012), and Åse Minde (Oslo, May 30, 2012). The interviews follow ethical and scientific guidelines, and are reported to the Norwegian control agency, Norsk Samfunnsvitenskapelig Datatjeneste.
} 


\section{Aesthetics and mental health care}

The history of psychiatry is full of violence and contains dark chapters from witch burnings to "houses of fools", where the mentally ill were described as "obsessed". Later, in many countries, there were upheavals to establish a more humane approach; one of the important reformers was the French psychiatrist Philippe Pinel (1755-1826), at the Bicêtre Asylum in Paris. By replacing force with care, he sought to develop a radical change in treatment of the individual patient. In Norway, a law regarding the insane was introduced in 1848 , following a report from psychiatrist Herman Wedel Major to the Ministry in Copenhagen. This lead to the construction of Gaustad Hospital, in 1855, which became our first scientific 'institution-led recovery', based on the principles of isolation, classification, and activity (Lysnes, 1982, p.90, White Paper 25, 1996/1997). At the turn of the nineteenth century, many new hospital services were established where patients lived, and in 1914, the psychiatrist Jens Henrichs described how remnants from the old days were avoided and how one sought to raise "bright, friendly buildings with exteriors sought kept in the same style as ordinary hospitals" (Henrichs, 1914, p.16).

Gradually, the views on what was considered helpful, and on where the help should be given, have changed in the field of mental health care. The institutionally defined hospital treatment has come to be seen as an additional burden and over time, hospitals have developed clear ambitions to become more open. In a white paper entitled "Åpenhet og Helhet" (Transparency and Coherence) (White Paper 25, 1996/97), written to the Norwegian Parliament, a decentralization in the organization of treatment services was stated. Psychiatric hospitals were to be downscaled, and people were to get help in their local communities. Nonetheless, these goals have been countered by other recent developments in new public management (Rønning, 2011), which suggests a re-centralization due to economically and politically based health care reforms (White Paper 47, 2008/2009); therefore, it has again become important to emphasize the quality of the treatment and to investigate its conditions. As philosopher and sociologist Michel Foucault showed through his Histoire de la folie (1961), the way we treat our mentally ill is also a history of our societies and about our definition of normality. The increased medicalization and professionalization can also indicate a societal distance to mental fragility or illness. The way in which we classify and treat it is thus of importance, but so is the way we keep people and how they, because of this, are able to inhabit physical spaces. That is, in what way do we create and enable "life forms" through architecture, interiors, and sensuous landscapes, and to what extent are we aware of the different possible forms of sensuous impact and interaction in mental health care?

Even if the environments for mental health care is an area of continuous interest in practice, health researchers have documented a lack of sensuous awareness in most health care environments with a low degree of attention paid to aesthetic qualities and strategies concerning environment and interiors (Daykin, Byrne, Soteriou, \& O'Connor, 2008). Similarly, in psychosocial medicine, the nurse and 
professor in art and health, Britt-Maj Wikström, has argued that too little research has been done on patient and staff interactions with sensuous or artistic material in hospitals (Wikström, 2004). These findings can be seen as interactive strategies to the aesthetic experience of the environments, and what is to be understood as "aesthetic quality" then emerges as a central topic. Aesthetics, as described by the art philosopher Nicolas Bourriaud (Bourriaud, 2002), is strongly connected to art as relations, and this perception of art is an understanding that might be very relevant, but it is a perception of art that is seldom included in mental health care studies (Repper \& Breeze, 2007). Accordingly, inspired by relational aesthetics, in this article, "aesthetic quality" is defined to be the relationships between art, people, and their sensuous environments in mental health care. It is further discussed how relational aesthetics can contribute to an art didactic approach that also is relevant in mental health care and well-being. Our frame of art didactics is related to the study of interaction between people and art in various contexts, and with various intentions such as reaction, reflection, relaxation, awareness, learning, and activation (Christensen-Scheel, 2013b). In this context, we examine how these relationships can be expressed in psychiatric institutions, and how art can contribute to the creation of new possible sensuous landscapes.

\section{From physical shapes to life form in art theory}

Emerging from recent aesthetic theory (Bourriaud, 2002), the concept of relational art is, for many, a new way of understanding art. Bourriaud sought to open the field of art to relations, to the creation of encounters, rather than to the experience of a closed off and clearly defined material object. This movement in the twentieth century is often referred to as the "de-materialization" of the art object roughly beginning with Marcel Duchamp putting a ready-made urinal, with his signature as the only mark of origin, into the art institution in 1917. He also signed the urinal with "R. Mutt", which could be read as the German word "armut", meaning poverty. Therefore, the work also had a conceptual side pointing to the societal conditions alongside the value of the art and its institution. However, this outward-seeking contextualizing tendency not only characterizes a form of art production, it also characterizes a form of art experience and a "mode of analysis". As the German philosopher Gernot Böhme describes the development in aesthetic philosophy, he points out how aesthetics, as a discipline during the nineteenth and twentieth century, became a "philosophy of art" rather than the broader theory of sensuousness and sensuous experience described by eighteenth century philosopher Alexander Baumgarten in his Aesthetica (Böhme, 2001, p.520). Among other things, this was tied to the need for a "reflected" or "constructed" sensuousness, as a basis for philosophy and analysis, an experience of the material nature was not in itself considered suitable for analysis, mostly because it was the object and not the experience that was the subject of analysis. Moving into the twentieth century, the development of phenomenology (Merleau-Ponty, 2003) and pragmatism (Dewey, 1958), expanded the field of study to include the subjective experience, pointing out that sensuous 
phenomena, as described by humans, is in fact always perceived or experienced by someone. The view of art is, in this perspective, not limited to the art object itself, or the physical presentation alone, it also includes the subjective perception of the viewer.

This subjective perspective in aesthetics was thus established in science and further led to the awareness of context and contextualization; specifically, if phenomena are experienced, they relate to specific people but also to specific and changing environments that also must be taken into account in the analysis. In itself, this fluctuation, or dynamic of meaning construction, is what is emphasized in much so-called post-structuralist theory, primarily indicating a turn away from a positivist science paradigm, which is centered on the production of a true or actual reality (Deleuze \& Guattari, 2004, p.6). In this context, it does not mean that phenomena cannot be grasped or that they do not need to be explained, but that aesthetic theory has seen a move away from an analysis of the art object in favor of a movement toward an analysis of the aesthetic experience, relation, and context. This necessarily makes the theorization more flexible, or dependent on precisely the constellation of specific experiences, relations and contexts.

During the 1990s, Nicolas Bourriaud developed relational aesthetics, the specific strategies of spectator involvement, in a relational theory of art (Bourriaud, 2000). In an avant-garde tradition, he sought to promote and develop art strategies that surpassed the isolated object, the distanced experience of it, and the primary focus on art's autonomy. Emphasizing the social, psychological, and societal possibilities for art, Bourriaud suggests several forms that transcend the structure of closed-off objects. One important fluctuation that Bourriaud created lies in the term "form", connecting material and immaterial form and further relating the choice of form to the "form of life". In an art context, form had primarily been tied to physical forms and shapes. However, this new perspective was also indicative of the complex activity of forming and composing, thereby indicating a manner of doing, a manner of interacting with the physical material. While this chain of argument is complex, at the same time, it is intuitively graspable; the way we shape our environments and the way they shape us are made up of both material and immaterial factors. Bourriaud suggests that they are intricately connected, and that the ways in which we interact with our environment, in both material and immaterial ways, are the ways we form our lives. Further, he suggests that several contemporary artists use an aesthetic perspective on how we conduct our lives - our everyday life and sociality is aestheticized (Bourriaud, 2003, p.16,140). This could be seen as making life into an object structure or to objectify life, but it could also mean to analyze the sensuous components of our environments and activities. For the study of the two wards in mental health care, we are directly building upon this inclusion of our immediate and everyday environments in aesthetic research, and the importance given to them. The consideration of the relational and communicational character and potential of art in combination with the material and physical qualities, is a recognition of the always material and immaterial sides of a life. The theatre theoretician Willmar Sauter provides a complementary 
explanation of the relationship between the material and the immaterial sides of art (2000). He describes "communication" as the goal of theatre, nevertheless, the theatre "object" or play is something in itself. Based on phenomenological as well as hermeneutic perspectives, he develops a model that seeks to grasp the interaction between production and reception - produced (material) qualities and perceived (material) qualities.

The interactional terms of this model of theatrical communication are used in the discussion section of this study to analyze the relationships between the existing world (material and immaterial) of the patient/staff and the potential or produced world constituted by art or environment. On the one side of the model, is 'presentation', that which is external to the subject/patient - and on the other side, we find the subject's 'perception' of a situation or environment. Sauter further identifies three perspectives in both presented and perceived material: sensory, artistic, and symbolic. 'Sensory' is the immediate material and sensory character of an object or expression. 'Artistic' is the knowledge related to the object or expression. Finally, 'symbolic' is the interpretational or deeper level, which might be both personal and/or (inter)contextual. These three levels will be used in this context to frame and characterize the aesthetic qualities or strategies related to the mental health care in the wards at Skytta and Gaustad. Sauter also places this model of communication within an overall structural or societal context, indicating discourse led factors (Foucault, 1971) as well as economic and cultural conditions (Bourdieu, 1993). Finally, Sauter incorporates this in the subject's life world, with reference to phenomenology and Martin Heidegger, or if we return to Bourriaud, to the individual, the potential life form in relationship to people and environment. Nonetheless, in this article, we will concentrate on the perceptional levels.

\section{To keep and to cherish}

The keeping and placement of mentally ill individuals has been the subject of different forms of legislation throughout history. These legislations have reflected the respective society's view on mental illness; Michel Foucault reflected upon how it has also indicated the borders of society and "normality" (Foucault, 1961). More recently, arguing that it, as such, is an important identity arena and a creator of safety, the sociologist Lars M. Ulfrstad addressed the importance of the building as both a place of recovery and a residential area (Ulfrstad, 2007). The lawyer Elisabeth Brodtkorp and the social anthropologist Marianne Rugkåsa point to the symbolic function of a residence in general, and its social, cultural, and economic position in society (Brodtkorp \& Rugkåsa, 2007). 


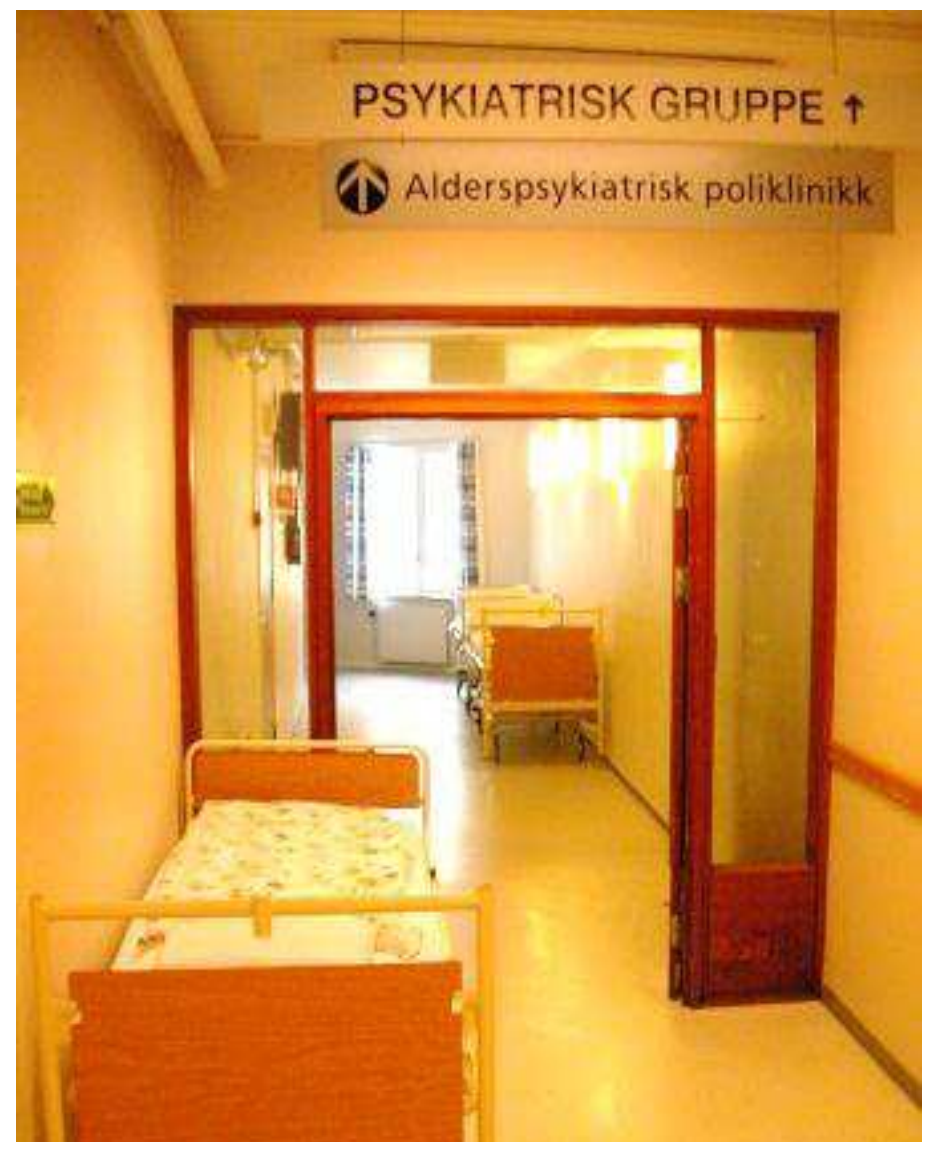

Picture 1: Interior of the old hospital at Lørenskog.

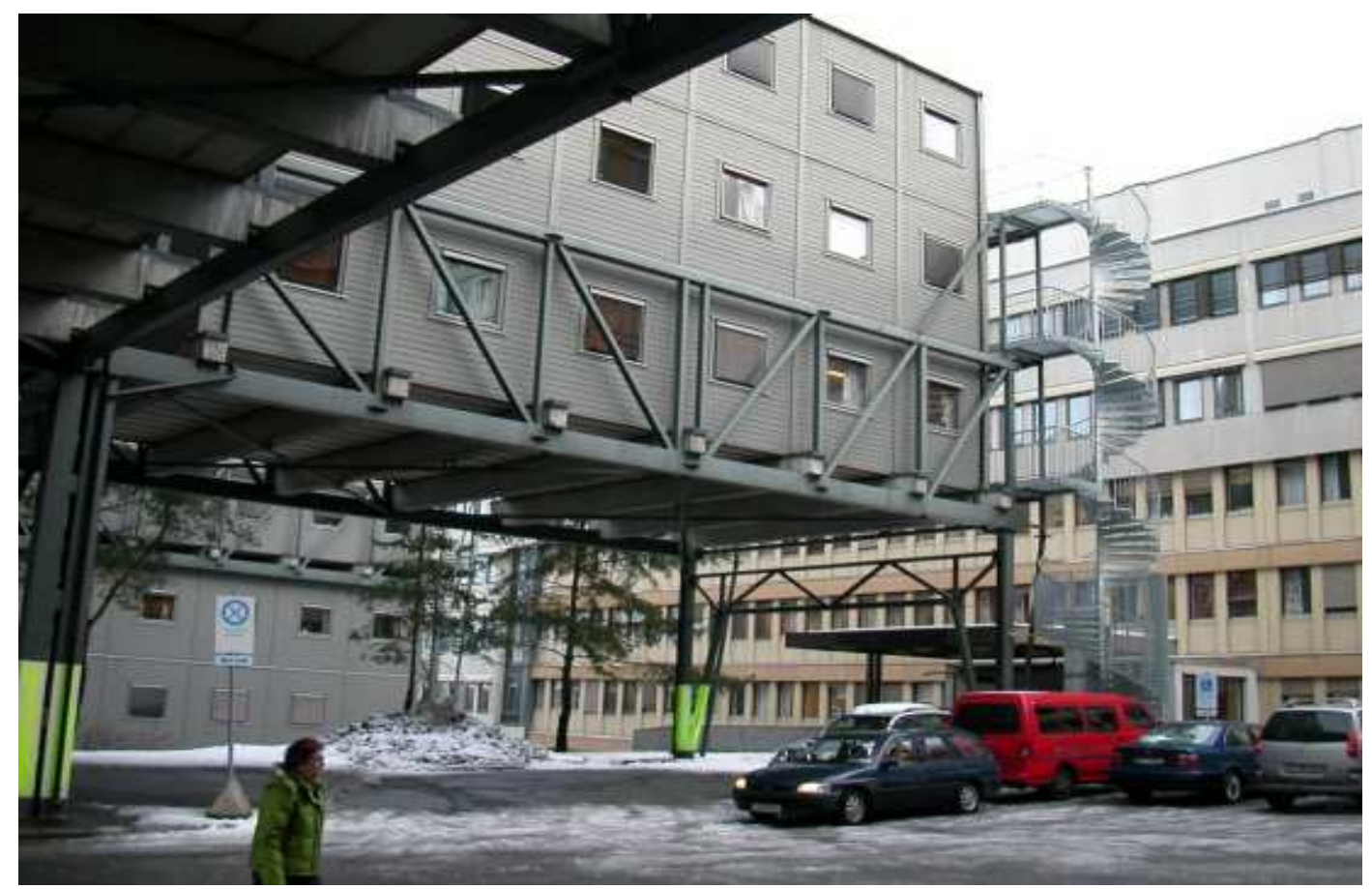

Picture 2: External hospital façades of Akershus University Hospital - the old hospital was being rebuilt in 2010 (Lørenskog). 
The psychogeriatric ward was originally situated at Lørenskog, but because of a rebuilding, the ward was temporarily moved to another location. The picture above shows the aesthetic environment at Lørenskog before it was moved to Skytta (Picture 1). The new location was a building that had previously been used by AGFA Film - located in an industrial area, with a shipping firm and an ice cream factory as the nearest neighbors. The exteriors are flat and functional, similar to the other industrial buildings nearby, and it was built in a functional style (Picture 2). The newly remade interior walls were mostly empty and white (Picture 3), and the staff expressed a need to put something on the walls to create a more "homey atmosphere" in the corridors and in the common space. This was within the locked ward, but outside the patient rooms.

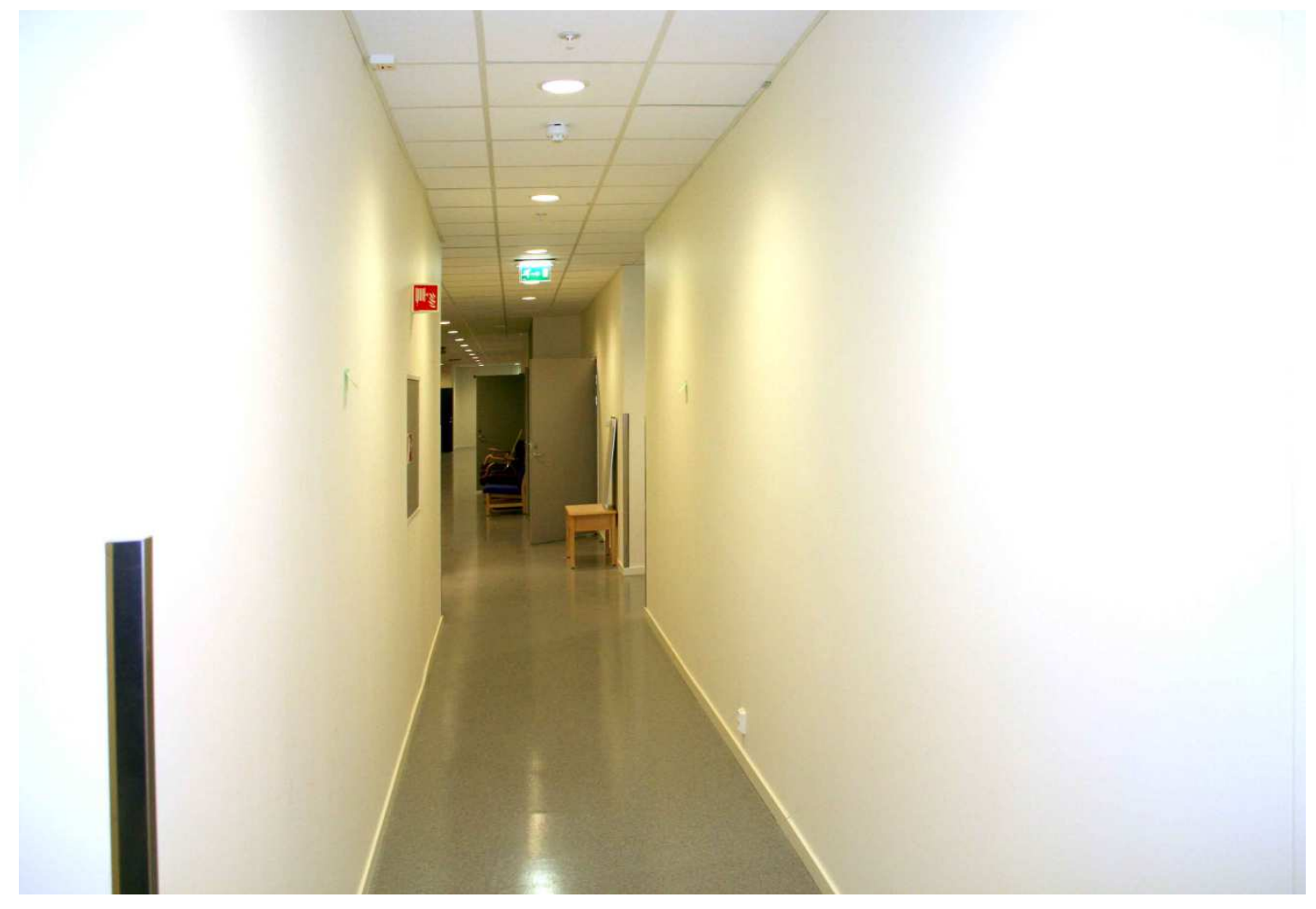

Picture 3: Interior from the new ward at Skytta - before installation.

Because of the forced moving of the ward, it can be said that the place was marked by a resignation among employees just starting the process of re-establishing the ward. A group that was to take care of the interior decoration was established among the staff, to buy images and furniture that could fit into the ward. As a part of Arild Berg's artistic contribution, it was agreed that some of the staff was to take part in the development of new art objects, and that the "interior design group" was to take part in the placement of the art projects in the ward. 


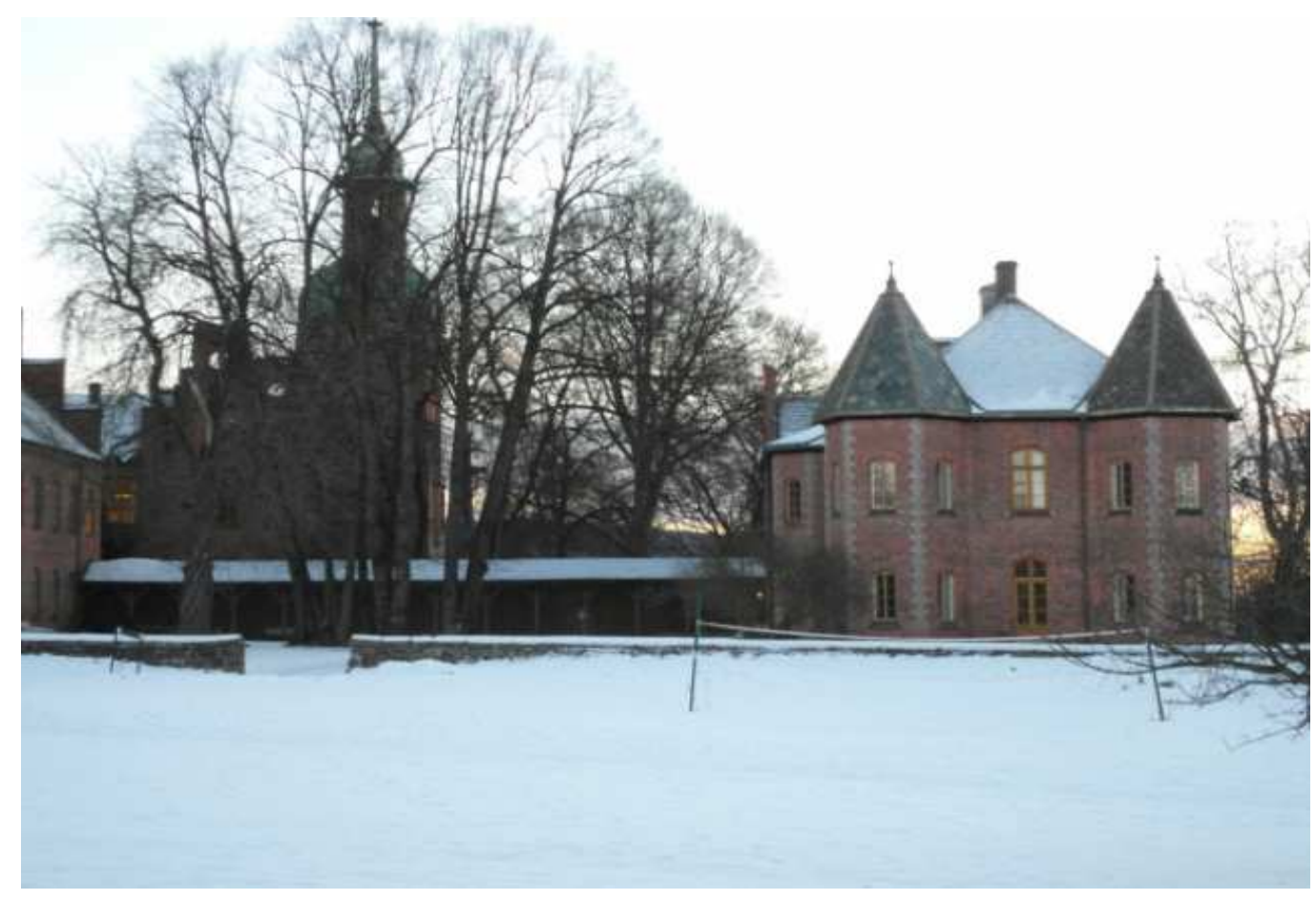

Picture 4: External facade from 1855 at the current ward for eating disorders at Oslo University Hospital (Gaustad).

The aesthetic environment of the Special Clinic for Eating Disorders at Oslo University Hospital was in many ways different. The clinic was established in 2001 in collaboration with art therapist and psychiatrist Åse Minde. Her particular awareness regarding the physical environment, as well as the use of different methods of art therapy, gave rise to a more conscious attitude toward both existing forms as well as possible ways of forming in the psychiatric ward. The buildings at Gaustad (Picture 4), where the clinic is situated, are part of the "neo-gothic" architecture from 1855. The red brick buildings have archways, and stone walls, and are located near the woods, thereby giving a nearness to the natural landscape. This architecture constitutes a strong formal, architectonic, as well institutional context for current mental health care - the historic buildings are simultaneously imposing and beautiful, but different from newly built health institutions. Arriving in this architecture in 2001, the art therapists sought to alter or adjust the interior. The changes that were done were thus as at Skytta, made without professional interior design consultants, and primarily through paint, curtains, furniture, pictures on the walls, etc. However, these changes were made very consciously, as the therapist stresses the importance of the environment and the atmosphere as health benefitting (Minde, 2012; Rød, 2012). Åse Minde, the leader of the clinic, said that she reacted to the sterile and impersonal environments in mental health care and that she noted the paradox in creating "unhealthy" environments for the most traumatized patients. Since that time, she has been "very concerned with architecture and the importance of the room and the environment" in mental health care (Minde, 2012). 
When they took over the painted white interiors of the historic building at the policlinic at Gaustad, they were concerned with colors and the use of golden and earth tones, which would, in their opinion, fit the building better, as well as creating a generally more comfortable and lifepromoting atmosphere. As art therapists, they also use art in the environment, for example, pictures and art posters are on the walls, pianos are in the two group rooms, and in the waiting room, there is an enlarged poem hanging on a banner (Pictures 5 and 6).

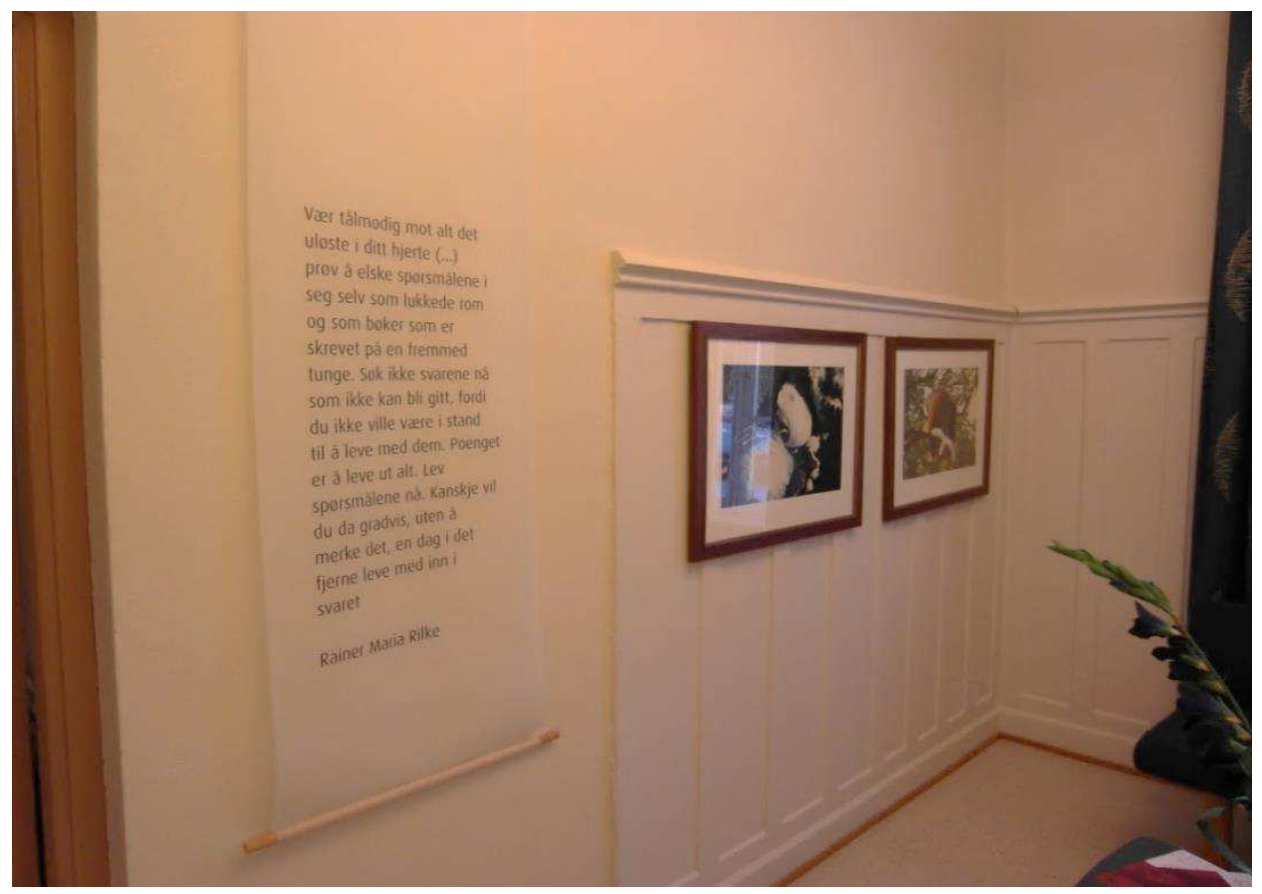

Picture 5: Interior with poetic text and images at the Ward for Eating Disorders (Gaustad).

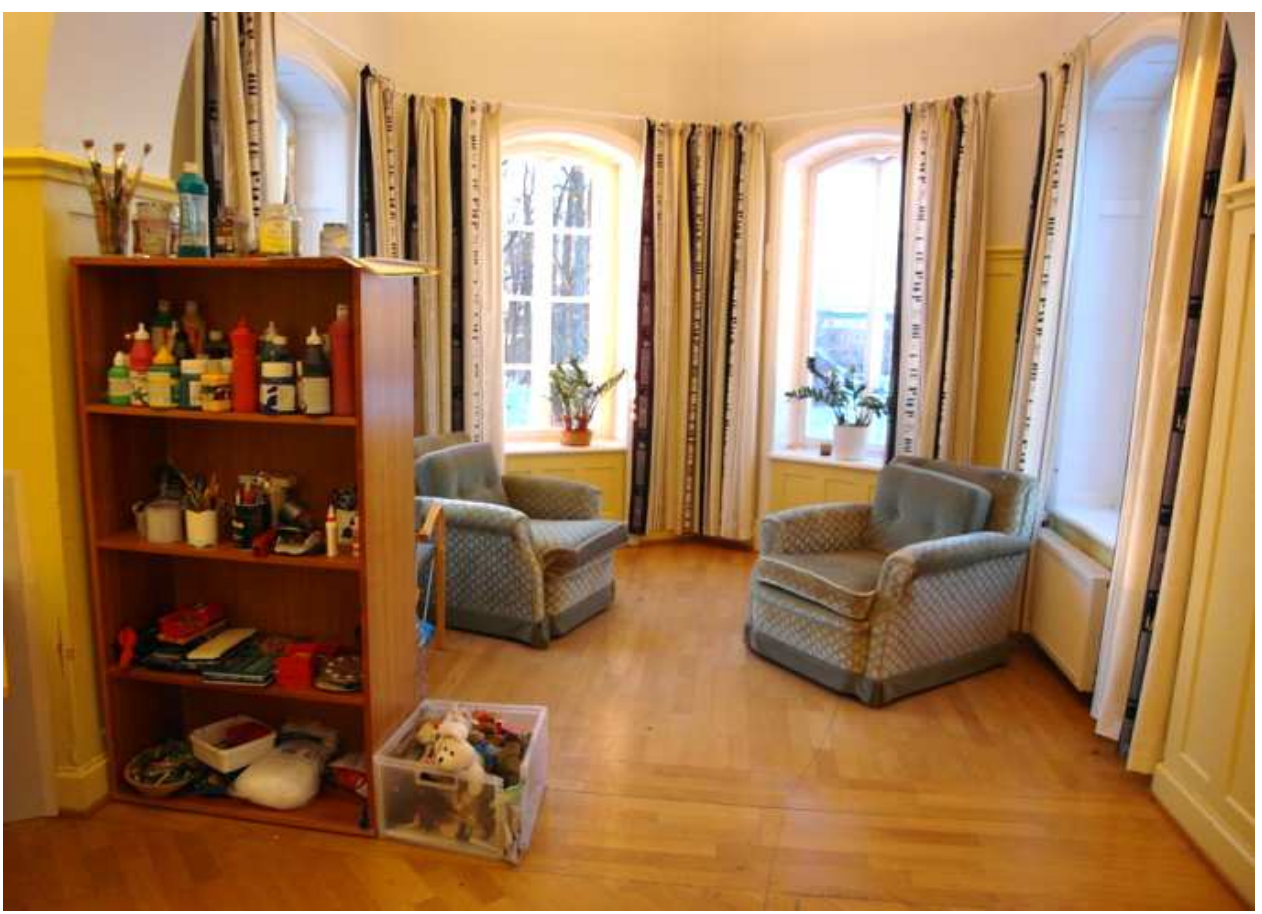

Picture 6: Interior with tools for aesthetic activities at the Ward for Eating Disorders (Gaustad). 


\section{Aesthetic activities and sensuous activation}

From the time psychiatric hospitals were established, activity has been central to treatment. Psychiatrist Jens Henrichs put it this way in his research in mental health care, "to support the efforts that strengthen the healthy ideas, feelings, forces, and to serve all, who can bring the soul abilities and nutrition, first and foremost work, adjusted to their condition, restorative and stimulating without overreaching their power" (1914, p.108). As a support for the patient, activity has been important since the time psychiatric institutions were established. Occupational therapist, Marit Borg (2006), points out how activity can help to leave the role of being ill and to feel meaningful. Another occupational therapist, Jytte Kokholm (2010), also indicates that creative activities are important to human identity formation, development, and mental health. This could be a matter of filling time, by creating something distracting; however, as a way of gaining or regaining recognition of self, it must be considered an important part of the improvement process. The creative activities take place both individually and in groups. Occupational therapists, Nadia Perruzza and Anne Elisabeth Kinsella (2010), analyzed 23 articles on the use of creative arts occupations in therapeutic practice, in the period 2000-2008. They suggested that the use of creative arts occupations in therapeutic practice might have important qualitative value related to health and wellbeing. Six predominant outcomes were most frequently identified across the studies: enhanced perceived control, building a sense of self, expression, transforming the illness experience, gaining a sense of purpose, and building social support.

One of the findings from the case studies was that aesthetic activity could be seen as a key to the inner landscape. Based on the study, although the main purpose of activity in mental health care is often seen as the raising of awareness for the patient engaged in sensory activities, it seems that the varieties within the scale of aesthetic activity can also have an artistic potential. But in a mental health care context, all activity can also be seen as positive for the sake of talking and making a contact. Activity creates both physical and mental movement; it could be an entry into something, a sort of key to the inner landscape. In the study at Skytta, the art objects were especially made for the place and mounted in the ward based on a dialogue with health professionals (Berg, 2010) (Pictures 7 and 8). 


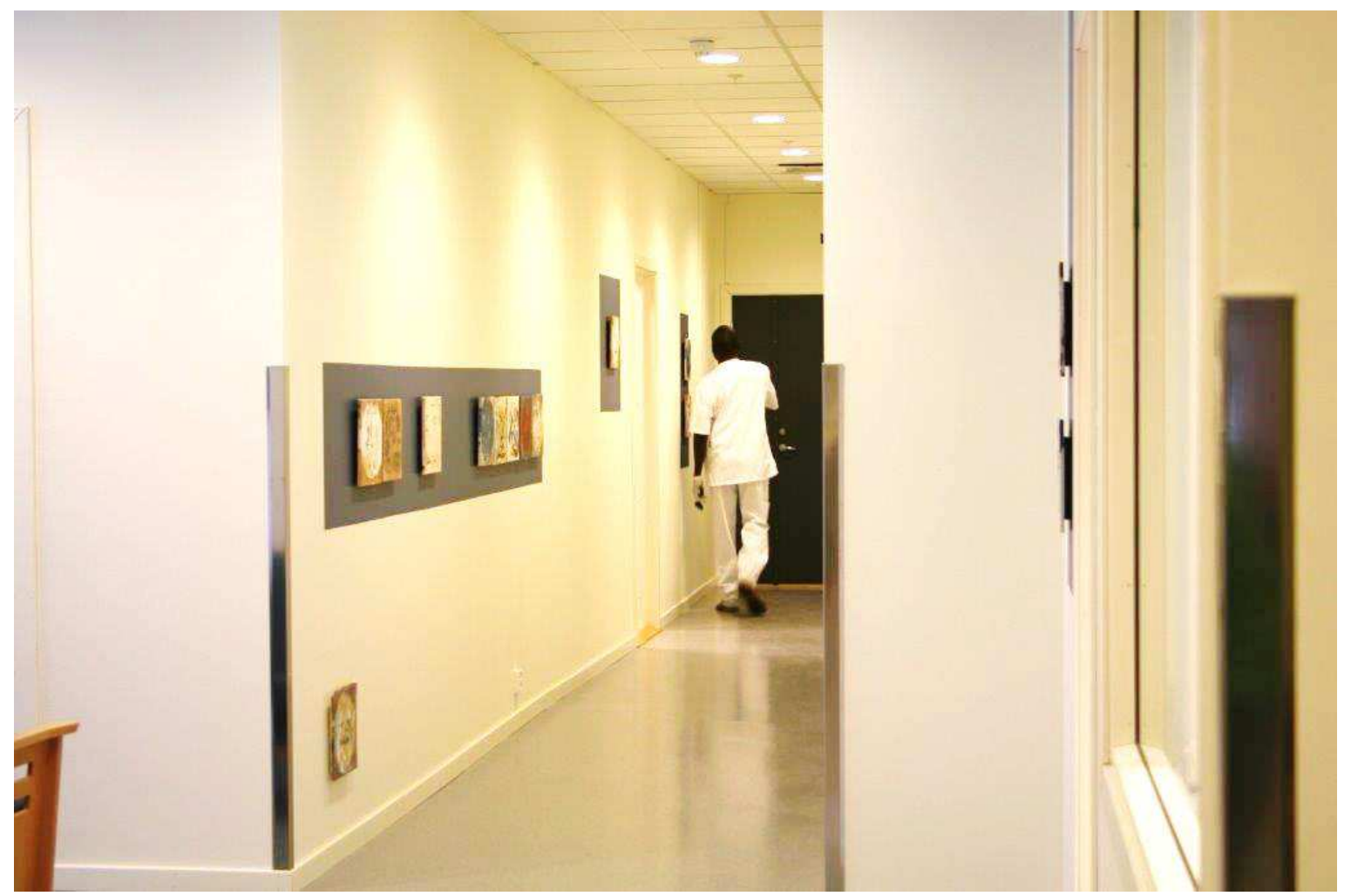

Picture 7: Interior from the new ward at Skytta - after installation.

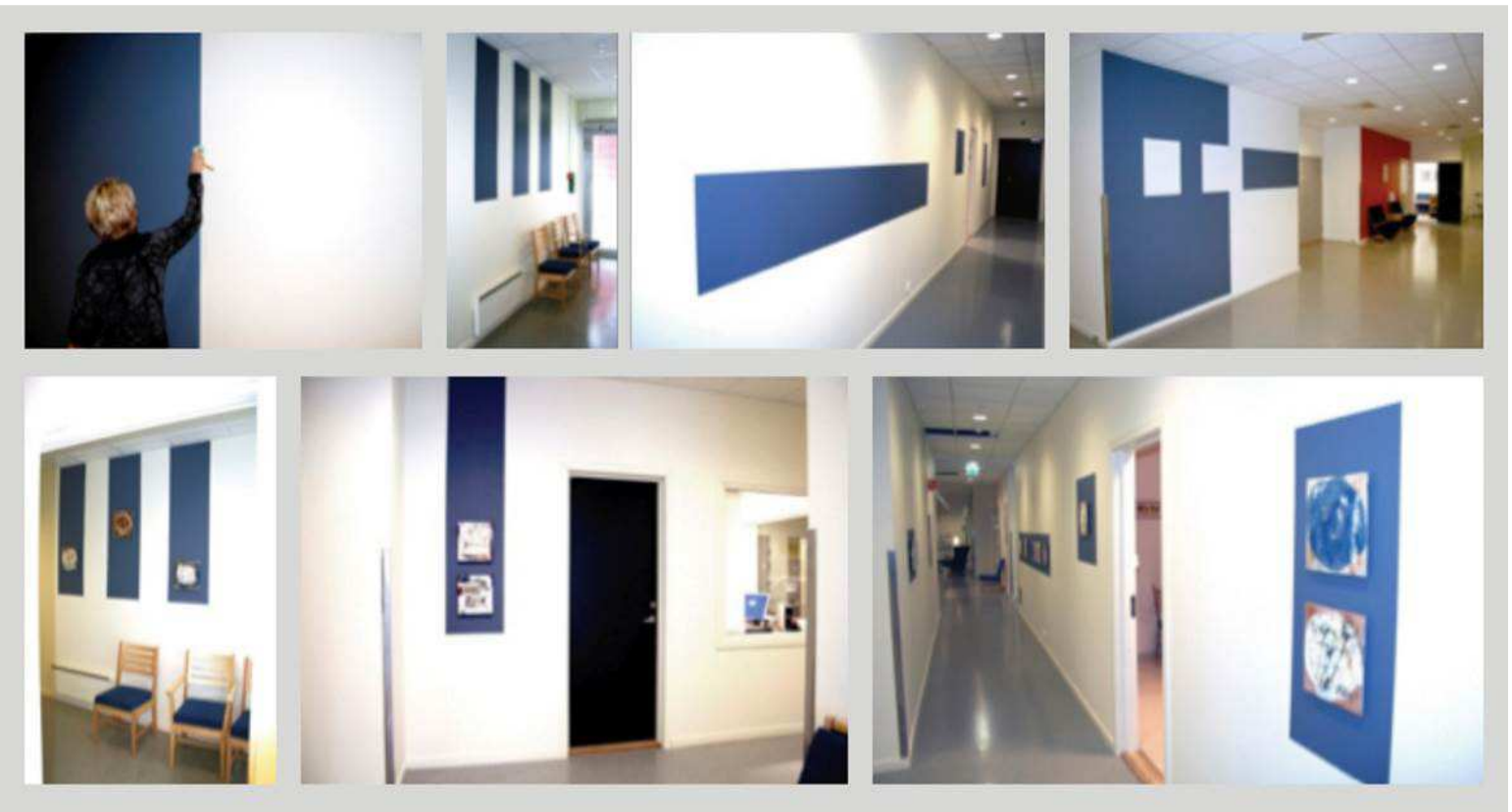

Picture 8: Identification of possible placement for the art was done in dialogue with the already established "environment group". The painting of the backgrounds for the ceramic images was based on an existing blue color in the ward walls. 
This activation around the art works in the environment was followed by initiatives from the staff, which were developed on the basis of earlier 'art dialogues' in hospitals (Wikström, 1992). Some of the following formulations were developed in the project, as possible conversation starters between staff and patients, "I am interested in showing you some of the visual artworks in our ward that you and I can discuss as a topic of conversation. Which of these visual art objects captures your interest? Describe the visual art object, what it represents. Pretend you are the artist and know all about the work: What does it bring to your mind?" These open-ended formulations around art and art objects created communication in different ways, both verbally and through body language, where eye movements and bodily positions were described as ways to understand the patient's mood in the situation (Ingeberg et al., 2012).

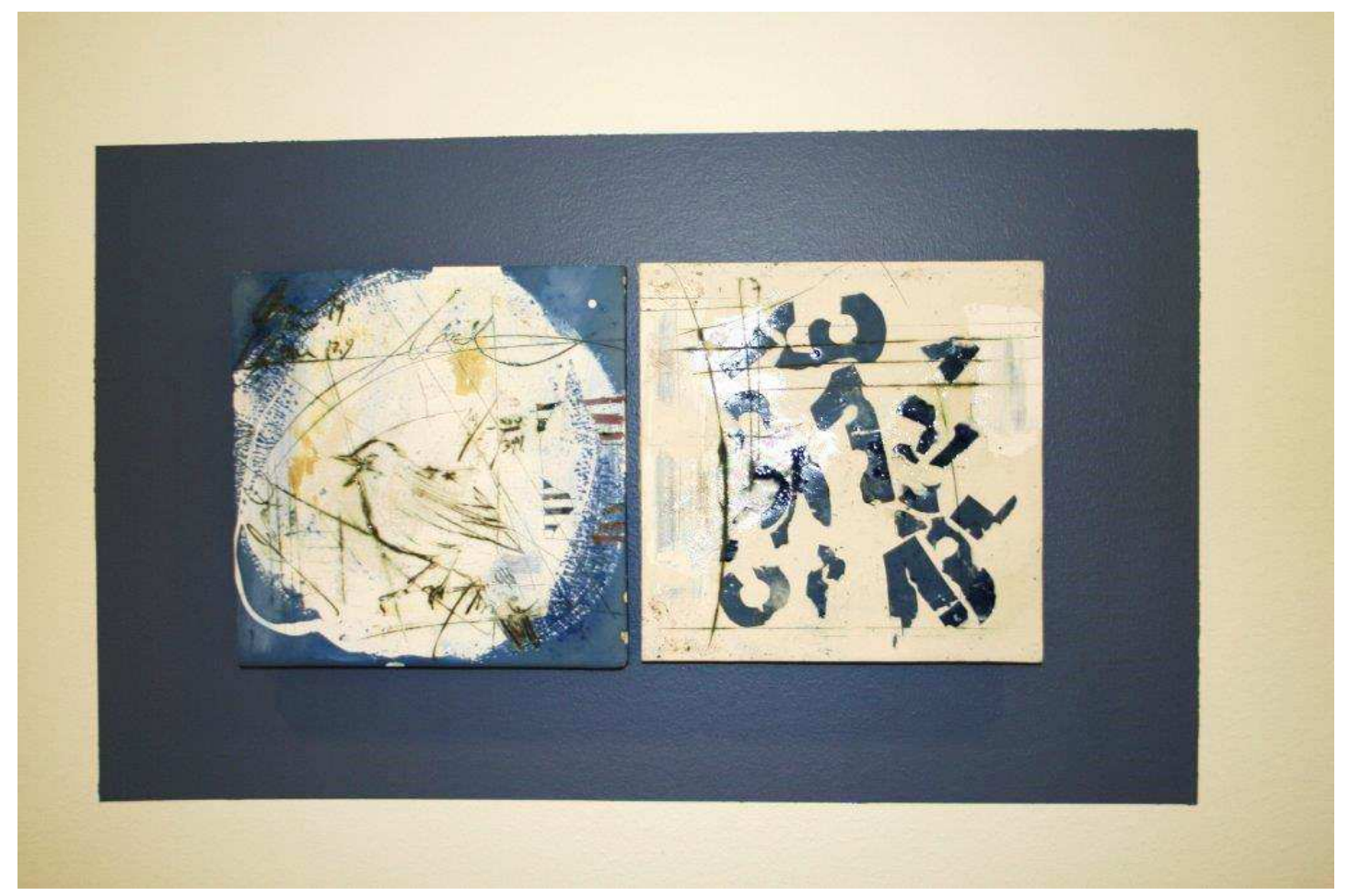

Picture 9: Examples of figurative and nonfigurative motives were combined.

Another outcome from the study at Skytta (Ingeberg et al., 2012) was that participatory processes is just as much an inspiration for artistic production. Twenty ceramic stones and twentyfour ceramic tiles were developed in a collaborative approach between health professionals, health researchers, and an artist (Picture 9 and 10). A dialogue with a patient became an inspiration for Berg in the artistic process of shaping an object with cloud motifs. The patient had commented on the abstract qualities from some of the first art installations, "I like non-figurative art because it reminds me of lying down on the grass looking at clouds in the sky, and imagining what the shapes can be." Another inspirational activity for the creation of art took place at a studio workshop with health professionals from the hospital. This workshop was the basis for developing several artistic concepts that could fit 
into the practice at Skytta. Outcomes were that there should be variation in the forms, as patients were different, both figurative and nonfigurative, and the art objects should not be dangerous or too upsetting. A leader at the ward said, "A scull is not suitable, I think." Following, the stones were considered too dangerous to be placed anywhere in the locked ward, so they were put in a light therapy room, which was a more controlled environment with group therapy dialogues.

Sensuous interaction can then be seen to help patients escape communicative isolation. The light therapy room at Skytta is one example. The interior of the room was mostly white with lightweight chairs in white fabric, white blankets, and soft lighting from the shelves. There was a CD player, so it was possible to listen to music, and the aim of the interior was to create a relaxing atmosphere before therapy or while getting therapy. The design of the room can be seen in relation to the principles of "snoezelen", a concept constructed from the verbs "snuffel", which means to seek out or explore, and "doezelen", which means to relax or to be half-asleep. The Dutch therapists, Jan Hulsegge and Ad Verheul, developed this concept to provide multi-sensory experiences and treatment for disabled children in the 1970s and 1980s (Flendt et al., 1994; Hulsegge \& Verheul, 1986). In the light therapy room stones of various shapes and colors were placed, some rested in a case of white marble sand that opened for a tactile encounter (Pictures 10 and 11). From the therapy sessions in this room, the staff reported that patients had been sprinkling sand on the stones during the therapeutic sessions. For some patients, the various types of interaction with art created memories and associations for further dialogue, which helped them to communicate around their situation.

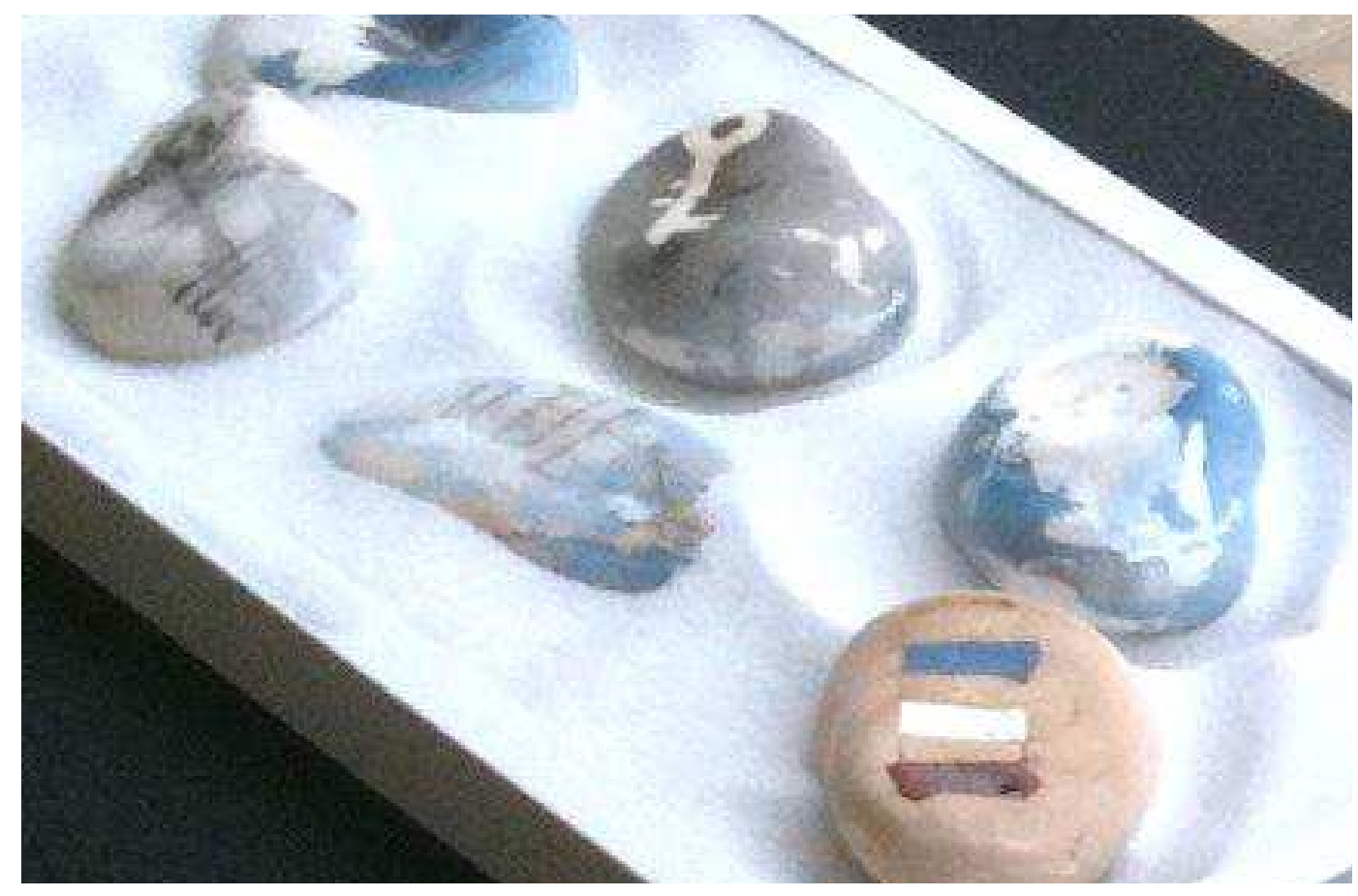

Picture 10: Stones in sand for the light therapy room - a result of artistic practice in mental health care. 


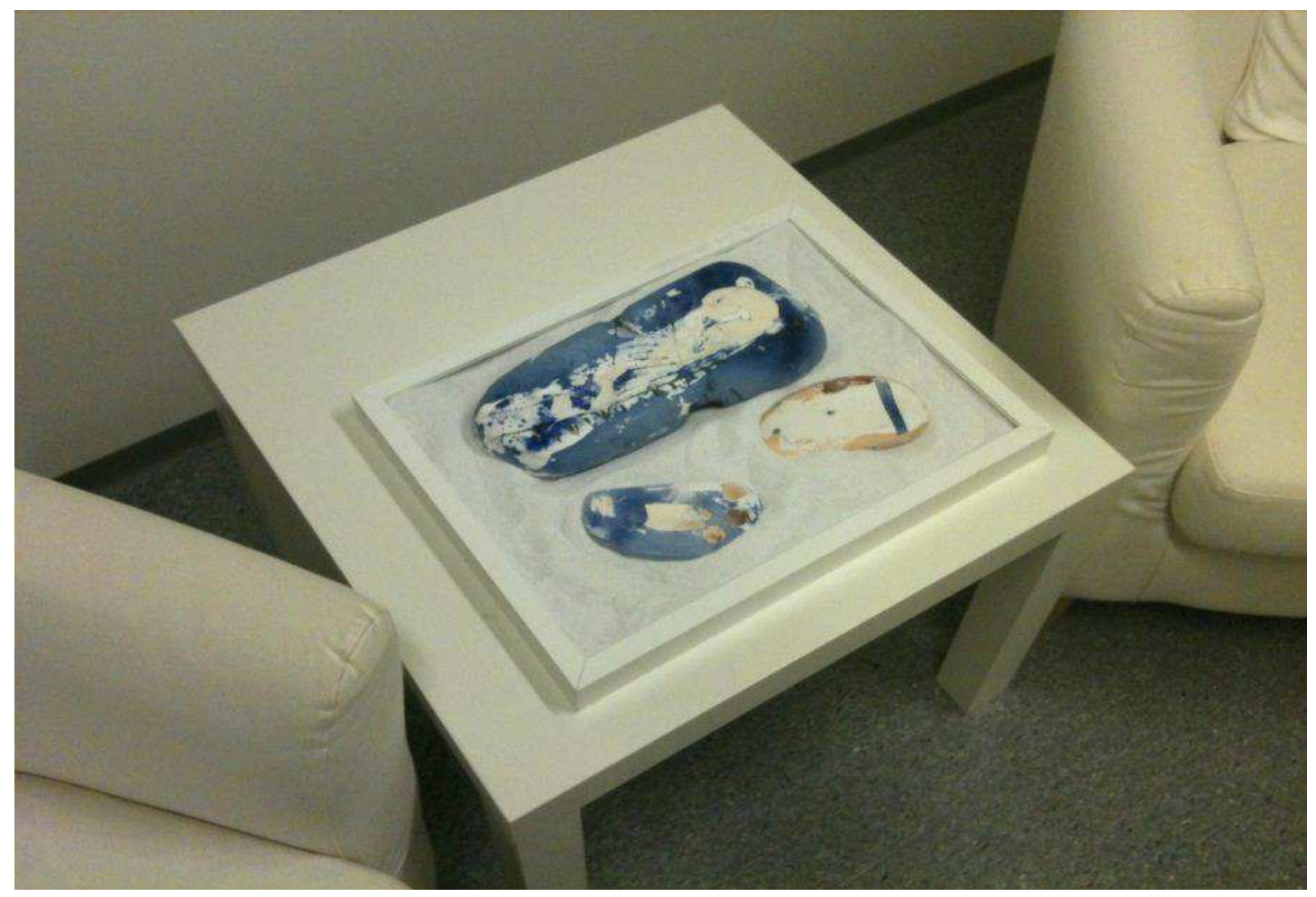

Picture 11: Stones in sand for the light therapy room - a result of artistic practice in mental health care.

We also saw that communication was enhanced through art-based body language. Before the stones were placed in the light therapy room, they were first placed in a basket in the staff's lunchroom. The stones were described as good to touch. A woman on the staff said, "Maybe it is typical women, but we all like to touch and feel the surfaces during the lunch break". By being placed in the lunchroom, the stones were sometimes used for group activities. One day, the physiotherapist had an idea to bring the stones to the morning session with the elderly patients. From this situation, the staff described the varying positions of the patients when they interacted with the stones: Body positions and facial expressions were seen to work as a physical communication regarding their thoughts.

Similar to the psychogeriatric ward at Skytta, one of the findings at Gaustad was that it is an aim to establish a communicative space for patients with eating disorders (Pictures 12, 13, 14, and 15). As therapist Kari Rød explains, patients with eating disorders can often be described, as having "closed off their sensuousness and their sensuous stories - the art therapist seeks to bring these forth, to formulate or materialize them" (Rød, 2012, p.1). In the interviews with the therapists at Gaustad, one of the striking observations was the diversity of their therapeutic practice in relation to art and sensuousness. Therapists Åse Minde, Kari Rød and Bjørg Standerholen, are trained in art therapy, but it could also be said that they have an increased awareness toward the sensuous surroundings as important factors in mental health care in general. The methods that are applied range from the use of an existing art object, such as a painting by a known painter, to a piece of music, a poem, or another object, for example, a photo of a casual place, a material, or an object in the room, a bowl, or a type of 
paper. Furthermore, sometimes the patients execute different forms of art practices, as they themselves chose or that the therapists suggests individually - this could be painting, drawing, sculpting/making cocoons, sewing, or writing. Other sensuous practices at Gaustad, such as eating together, dancing, or resting with ball blankets can also be considered as part of an aesthetic awareness or sensuous strategy. The aesthetic activities had value in relation to the therapeutic aims. This diversity of sensuous and art based approaches used in their mental health care indicates an awareness toward art methods and art objects, and more widely toward sensuous objects and activities. Based on their specific story and character, patients are thus invited into various creative activities at the ward. This creates relations to the physical forms and the sensuous apparatus through both awareness and the patients' own direct forming. The different therapeutic art practices can thus be characterized as an overall combination and use of aesthetic strategies and art based knowledge.
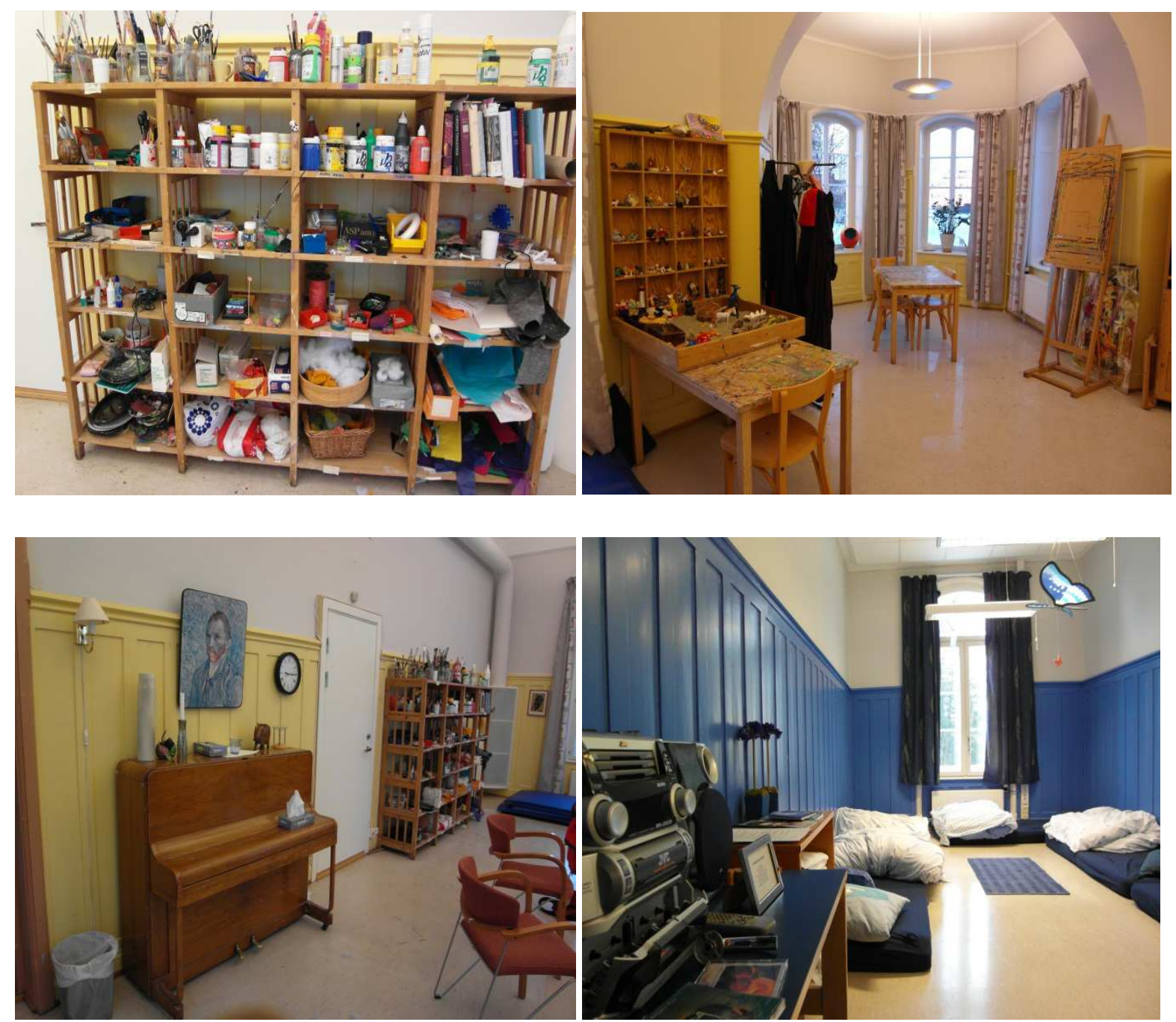

Pictures 12, 13, 14, and 15: Shelves and interior with objects for aesthetic activation such as painting, paper, and glue. Bottom right: The blue room, a room for relaxation with ball blankets. 
Berg, Christensen-Scheel and Ingeberg: Forming Life

One of the reflections we made after the two studies at Skytta and Gaustad, was that the environment can work as a physical connection to creation of meaning in the treatment, as well as in the lives of patients. One example used by therapist Åse Minde was the relationship a patient created through a porridge bowl: The patient was encouraged to eat a bowl of porridge each day for a week. After a week, the patient came to the clinic and the therapist asked how the eating was going? The patient answered that she had taken out the bowl of porridge every day from the refrigerator, but on Sunday, the porridge had grown mold. The therapist was surprised at the patient bringing out the same bowl of porridge every day, instead of making new ones, and tried to find another entry to the situation. As art therapists, they transfer or use aesthetic material, objects and stories as such entries, and the therapist decided to ask about the bowl itself - what did the bowl look like? The patient said that the bowl was ornate with small flowers and had belonged to her grandmother, a very important person in her life. From there, the therapist could use the reference to the grandmother as an incentive to eat. In some way, the bowl created a physical connection to important levels of meaning for the patient and, by the next week, the patient was able to eat the porridge (Minde, 2012, p.7).

Environments can also directly contribute to awaken or calm the body: At Gaustad, they have, similar to the mentioned snoezelen principles (Flendt et al., 1994, p.12; Hulsegge \& Verheul, 1986), created a special blue room, where a more sensuous or physical relation to the environment can be developed. The walls are painted blue, there are mattresses on the floors, there are pillows and some blue decorations, among other, a butterfly, a stereo to play music, and each mattress has a "ball blanket", a cover filled with plastic balls. The ball blankets cover the body, giving both a certain weight and a tactile feel - this can give a sense of safety, as well as being stimulating to a sensuously deprived body. In interviews, the three therapists, as well as the nutritionist (Standerholen, 2009; Minde, 2012; Rød, 2012; Forsberg, 2012), all describe the patients with eating disorders as being "cut off" sensuously, as being "in their head", suppressing the bodily needs of hunger or pain. For them, just to feel the touch and weight of the ball blanket can create a sensuous relation to the body, as it is awakened or calmed. The ball blankets thus have a particular tactile quality that creates a non-verbal and neurological reaction related to the patient's sensuous experience (Ward, 2008, p.31).

\section{An art didactic approach to aesthetics in mental health care}

Although indicating that the different sensuous approaches are creating possible life forms by forming the life within these wards, a complex understanding of the relations between "inner" and "outer" landscapes emerges from these different examples and strategies. Here, form does not only mean a particular shape, but as in Nicolas Bourriaud's theories, a way of creation or materialization that constitutes different possible ways of interacting with a material. For a severely traumatized patient, this could be perceived as less important than the general, and/or medical treatment. However, what is exemplified in the studies is that the actual possibilities each patient has in relating to and in 
materializing his or her environment, constitute vital and life-forming conditions in an otherwise controlled, and in many ways restricted situation. Some essential qualities identified in the examples from Skytta and Gaustad were that aesthetic activity could be vital to the development of mental health. It was shown how participatory processes could inspire an artistic practice and that sensuous interaction could help patients to escape communicative isolation. Further, it was also shown how artbased activities could enhance communication through understanding the patient's body language. Art could thus be seen to contribute to a communicative space in mental health care, and create a physical connection to memories and thoughts around a meaningful life. It was also shown how the environment could awaken or calm the patients' sensuous experience of the body.

While we emphasize these specific qualities from the examples, in this study it is not about an instrumental recipe to the use of art to produce a certain outcome; rather each situation was particular and had to be navigated specifically. One of the main benefits in this approach is that there are several entrances to the experience of art and several ways of creating it. Relational and contextually oriented (art) theories can be said to have had implications both for the perception of/and inter-action with "regular" art objects, as well as for the perception of/and interaction with non-art objects and environments (Bourriaud, 2000; Böhme, 1995, 2001). The possible contextualizations and recontextualizations of an object or situation put the object in relationship to the people perceiving, and not merely to the world or references produced within the object itself. Specifically, a painting or an environment is always perceived or used by someone, and it is through this particular perception or use that the different levels of meaning occur (Sauter, 2000, p.101). In a mental health care environment, this could imply an awareness of the meaning created by the different aesthetic contexts and the personal use/perception of these. The acknowledgement of these atmospheres and meanings created by aesthetic objects and surroundings (Böhme, 1995, p.21), must then in our opinion be considered important as a complementary approach in mental health care, creating different forms of consciousness and well-being. Artistic activities can help patients to transform their inner potential (Malchiodi, 2002) and contribute to dialogue (Ingeberg et al., 2012); furthermore, the environment and the aesthetic awareness itself can create important health-promoting factors.

Through a presentation of material from two wards, we suggest some perspectives on how art can be perceived and used in mental health care, as well as on how aesthetic and art based competence give rise to more qualitative aesthetic strategies, influencing possibilities for different life forms in mental health care. In our opinion, the aesthetic environments must be seen as both reflecting and producing mental states and "landscapes", and by using Willmar Sauter's perspective on theatrical communication, we might introduce further levels of awareness: The sensory level is the immediate material and sensory character of an object or expression. This could be how the interior first manifests itself in front of us, the first impression of a hospital interior and the patient's surroundings. This is relevant to the quality identified in this study of establishing a communicative space and to 
how the environment can awaken the body. The artistic level is related to the professional knowledge of the object or in the expression, that is, how the actors administer the sensory environments and dramatic (con)text. One example from the study was how participatory processes could inspire artistic production for a certain context. In a hospital, this could represent the professional awareness of the environment and how both health professionals, and patients see the possibilities in the active use of the environment through its connection to experience. This was exemplified in the study when health professionals took part in art dialogues that became "a key to the inner landscape". In the end, the symbolic level in Sauter's theories, the interpretational or deeper level, which might be both personal and/or contextual, is where the personal actualization occurs. The active use of elements available in the surroundings can create communication on a symbolic level, as is shown in the example of the porridge bowl. In the study, it was an everyday object, which, through professional guidance, created a physical connection to the creation of particular meaning for the patient. In general, the conversations based on art and environment can lead into therapeutic conversations, and in different ways to empowerment of both patient and staff, to personal development, and to morebeing (Ingeberg et al., 2012). The symbolic level can mean the patient's internalization of an art object or a deeper aesthetic experience of an everyday object. The art in the study created specific and individual relations based on a wider aesthetic context, and can thus be seen as a co-producer of inner and outer states.

Paying attention to the forming of the environment at the two wards, we noticed how the shaping of the interiors, to some extent, was defined and lead by the activities and the activation that was intended to happen in them. The therapy rooms and the waiting rooms at Gaustad are intentionally decorated (light, colors, pictures, furniture) and organized (furniture, piano, stereo, books, mattresses, paint, fabric, TV, poems, etc.) in ways that directly or indirectly activates. In these cases, the relationship between the environment and the activity are mutually dependent, as one of the goals for the patients is to refind activity, the environment reflects this. At Skytta, the art in the environment stimulated communication and thus was a key to the inner life of some patients. Specifically, having acknowledged the importance of sensuousness in general, both in art, as a therapeutic form and more generally, as a sensuous environment for the embodied mind (Fischer-Lichte, 2008, p.99), the interiors are no longer passive surroundings to activity, but seen as practiced places (de Certeau, 1988, p.117). Turning the argument around, a possible deduction is that an environment that expects a passive patient, in fact, further inactivates the patient. However, when shaping both the interior and the tools to stimulate sensuous activity - through music, painting, sculpting, dancing, eating, reading - the inactive patient is given different modes and forms of activity, from the mere visual perception of color on walls, furniture, curtains, to the more intricate sensuousness of visual art and music. Further, the patients are given choices between more delicate sensuousness, through the reading of a known poem, 
or just picking out a song, to the more self-delivering activity of creating a practical, artistic project (Minde, 2012; Rød, 2012).

In these cases from mental health care, paralleled with Sauter's theory of theatre communication, there seems to be a merging of environment and activity, inner and outer states realized through an aesthetic awareness. As environment and activity are intrinsically connected, the environment can function as an activating force, through sensuous stimulus, activity, and the creation of dialogue. In mental health care, where patients in some ways can be said to have lost their ability to be active in regular ways, the environment and ways of thinking art, as sensuous environment and activity, can gently activate and empower the patient. Using this aesthetic awareness in the wards for mental health care implies a recognition of the impact and meaning, even of trivial surroundings and the complex components of which these surroundings consist, involving personal, social, physical, and abstract relations.

\section{Empowering strategies in art and health}

Communication in mental health care could, in our opinion, be enhanced by a dynamic interrelation between people and environment, where more-being, as a sort of inner growth, can occur. Our examples demonstrate how environments are connected in different ways to people. In a mental health context, the borders between art and environment are becoming blurred; therefore, there must be ethical considerations when involving patients in a hospital as participants in art projects. We do however argue that forms and sensuous potentials are influential in empowering patients, and that the mutual influence between art, environment, and people in a hospital has an essential ethical value in the aim to give the patient better health. Researchers in social medicine Janecke Thesen and Kirsti Malterud (2001) argue that 'empowerment' is about mobilizing and strengthening people's own powers, as well as neutralizing the forces that allow feelings of inability. This is necessary for patients to get well and stay healthy, and often to counter the effects of suppression based on societal conditions, sometimes maintained through medical practice. Following, an extended focus could be on research with the relationship between materiality and immateriality, and on ways that people are influenced by art and sensuousness in their habitat.

The reflections of artists on the creation of works of art can further contribute to an expanded understanding of the life cycle of artefacts and the use of art in the environment. How art can be created in a particular social context, is a specific approach that can inspire artistic production as well as contributing to studies in material culture and in other areas concerning environmental issues. A social context involves several people and therefore the creation of social art can be explored further through multiple perspectives. In a societal scope, it also becomes possible to show different ways to understand an art object and the situation around it. Further documentation of these perspectives could 
also be fruitful for other professions, where an increased awareness of the sensuous dimensions of a social context is needed. Such documentation can strengthen access to relevant experiences for artists where the social practices surrounding the art are a part of their art strategy (Knowles \& Cole, 2008).

The goal of this study was to contribute to filling the knowledge gap between art didactics in contemporary art practice and sensuous awareness in mental health care. Through incitement and possible change in established practice, an alternative room is sought, where a wider variety of methods can be applied, in mental health care as well as in art practice. In practice, the implications of the study have been to contribute to knowledge transfer by the identification of an expanded epistemological framework with relevant topics - the architectonic frame, the overall interior, the use of art objects, art activities, and art based knowledge can give professionals a wider range of health promoting tools. For nursing students in mental health care, knowledge about how patients can be more actively involved in their environment is important. To create activating and stimulating contexts, professionals in mental health care should be able to use sensuous strategies as a part of everyday practice (Ingeberg et al., 2012). For art practitioners, it is relevant to be able to reflect aesthetically along with ethical guidelines when developing art works with health professionals. In this context, a general competence for artists is to be able to work collaboratively with not only professionals in health care, but also in other non-art-areas of society. Through an identification of qualities of applied aesthetics in a mental health environment, the study has thus sought to contribute to developing contemporary art didactic perspectives in a mental health care context. Consequently, these new perspectives contribute to an expanded art field that includes mental health care.

\section{Acknowledgements}

Thanks to the representatives from Akershus University Hospital and from Oslo University Hospital for their collaboration.

\section{On the contributors}

Boel Christensen-Scheel is associate professor in aesthetics and art didactics at Oslo and Akershus University College of Applied Sciences. Christensen-Scheel holds a Ph.D. in contemporary art and performance theory, and her field of interest mainly concerns art's relational capacities from bodily experience, epistemology and didactics, to more explicit political and ecological projects. She has translated Nicolas Bourriaud's 'Relational Aesthetics' to Norwegian (Pax Forlag, Artes, 2007), worked as an art critic and more recently she has published an essay about Kjartan Slettemark's Nixon Series (Torpedo Press, 2010).

Arild Berg teaches in research methods and communication strategies at Department of Product Design at Oslo and Akershus University College of Applied Sciences. He is a Doctor of Arts Candidate at the School of Arts, Design and Architecture at the Aalto University in Finland, a school with the motto 'Pro Arte 
Utili', which means For Useful Art. He has studied participatory processes in public art and especially the role of the material based arts. His background is in ceramic art with several public art projects, see www.arildberg.no. He has held several positions of trust in the contemporary art field; a member of the national board of The Norwegian Association for Arts and Crafts (NK) and as board member of Norwegian Visual Artists Copyright Society (BONO). His aim is to explore how artistic research and artistic practice can take part in interdisciplinary research to enable more use of art in society.

Mette Home Ingeberg is a trained nursed who in 1969 specialized in psychiatry. Her work places include the hospitals of Ullevål and Blakstad. She majored in health subjects in 1994 and worked at the University College of Oslo and Akershus from 1987 until 2013, in later years holding a position as associate professor. Mette Holme Ingeberg has published a number of articles and books.

\section{References}

Asaro, P. M. (2000). Transforming society by transforming technology: The science and politics of participatory design. Accounting, Management and Information Technologies, 10(4), 33. http://dx.doi.org/10.1016/S0959-8022(00)00004-7

Aure, V. (2006). "Formidling av bilder til barn - som kunstdidaktisk diskurs". Tidsskrift for børne- og ungdomskultur Nr 51 / Kunstformidling for og med børn og unge. Odense: Syddansk Universitetsforlag \& Børne- og Ungdomskultursammenslutningen.

Borg, M. (2006). Arbeid, aktivitet og mening, I: Psykisk helsearbeid i nye sko, Red: A. Almvik \& L. Borge, Bergen, Fagbokforlaget.

Borgdorff, H. (2012). The conflict of the faculties: Perspectives on artistic research and academia. Leiden University Press.

Bourriaud, N. (2002). Relational aesthetics. Dijon: Presses du réel.

Bourriaud, N. (2003). Formes de vie. Paris: DeNoël.

Bourdieu, P. (1993). The field of cultural production. Cambridge: Polity Press.

Brodkorp E., \& Rugkåsa, M. (2007). Stig på, velkommen Inn! I: Under tak - mellom vegger I: Perspektiver på boligens betydning i velferdsstaten, (Red) E. Brodkorp, M. Rugkåsa. Oslo Gyldendal Akademiske.

Böhme, G. (1995). Atmoshphäre - Essays zur neuen Asthetik. Frankfurt: Suhrkamp verlag.

Böhme, G. (2001/2008). “Innføring” fra Aisthetik.Vorlesungen über Âsthetik als allgemeine Wahrnehmungslehre (2001), i red. Arnfinn B $\emptyset$-Rygg \& Kjersti Bale, Estetisk teori. Oslo: Universitetsforlaget.

Böhme, G. (2001). Ethics in context: The art of dealing with serious questions. Cambridge: Polity.

Carlson, A. (2001). Environmental aesthetics. In (Ed.) B. Gaut \& D. M. Lopes, The Routledge companion to aesthetics. London and New York: Routledge.

Christensen-Scheel, B. (2009). Mobile homes - Perspectives on situatedness and de-situatedness in contemporary practice and theory. $\mathrm{PhD}$ thesis. University of Oslo: Universitetsforlaget.

Christensen-Scheel, B. (2013a). "Den anerkjente betrakter.” Oslo, Artic Challenge - Site Specific/In Formation - Nordic Journal of Art and Research, in press.

Christensen-Scheel, B. (2013b). Application and Autonomy: The Reach and Span of Contemporary Art Didactics. InFormation - Nordic Journal of Art and Research, vol.2 n.2. 
Daykin, N., Byrne, E., Soteriou, T., \& O'Connor, S. (2008). The impact of art, design and environment in mental healthcare: A systematic review of the literature. Journal of the Royal Society for the Promotion of Health, 128(2), 85-94. http://dx.doi.org/10.1177/1466424007087806

De Certeau, M. (1988). The practice of everyday life. Berkeley: University of California Press.

Deleuze, G., \& Guattari, F. (2004). A thousand plateaus. London: Continuum.

Dewey, J. (1958). Art as experience. New York: Capricorn.

Flendt, H. (Ed.). (1994). Snoezelen som redskap til et bedre liv? Danmark: Solbo.

Fischer-Lichte, E. (2008). The transformative power of performance. London and New York: Routledge.

Forsberg, G. (2012). Interview by Boel Christensen-Scheel. Oslo.

Foucault, M. (1961). Histoire de la folie. Paris: Librairie Plon.

Foucault, M. (1971). L'ordre du discours. Paris: Gallimard.

Frayling, C. (1993) Research in art and design. Vol. 1. Royal College of Art Research Papers (1-5). London: Royal College of Art.

Ingeberg, M. H., Wikström, B.-M., \& Berg, A. (2012). The essential dialogue: a Norwegian study of art communication in mental health care. Journal of Psychosocial Nursing and Mental Health Services, 50(8)s, 22-30. http://dx.doi.org/10.3928/02793695-20120703-01.

Henrichs J. (1914). Sindssykepleien i dens grundtræk Kristiania, H. Aschehoug \& Co.

Hulsegge, J., \& Verheul A. (1986). Snoezelen - Another world. England: Rompa.

Kjønstad, A. (1992). Pasientrettighetenes framvekst. I: Kjønstad, A. og Syse, A. (red.): Helseprioriteringer og pasientrettigheter. Oslo: Ad Notam Gyldendal.

Kokholm, J. (2010). Ergoterapeutisk intervention med skapbende aktivitet I: Lærebog i psykiatri for ergoterapeuter og fysioterapeuter, Mungsgaard Danmark.

Knowles, J. G., \& Cole, A. L. (2008). Handbook of the arts in qualitative research: Perspectives, methodologies, examples and issues. Los Angeles: Sage Publications.

Kvale, S., \& Brinkmann, S. (2009). Det kvalitative forskningsintervju. Oslo: Gyldendal Akademisk Forlag.

Lipe, A. W., Ward, K. C., Watson, A. T., Manley, K., Keen, R., Kelly, J., et al. (2012). The effects of an arts intervention program in a community mental health setting: A collaborative approach. Arts in Psychotherapy, 39(1), 25-30. http://dx.doi.org/10.1016/j.aip.2011.11.002.

Lysnes, M. (1982). Behandlere og voktere. Oslo: Universitetsforlaget.

Malchiodi, C. A. (2002). The soul's palette: Drawing on art's transformative powers for health and well-being. Boston: Shambhala.

Merleau-Ponty, M. (2003). Phenomenology of perception. London and New York: Routledge.

Minde, Å. (1994). Fra kokong til sommerfugl. Oslo: Ad Notam/Gyldendal.

Minde, Å. (2012). Interview by Boel Christensen-Scheel. Oslo.

Mo, T. O., \& Hatling, T. (2011). NAPHAs forskningsstrategi for psykisk helsearbeid 2011-2016. Trondheim:

Nasjonalt kompetansesenter for psykisk helsearbeid - NAPHA.

Repper, J., \& Breeze, J. (2007). User and carer involvement in the training and education of health professionals:

A review of the literature. International Journal of Nursing Studies, 44(3), 511-19.

http://dx.doi.org/10.1016/j.ijnurstu.2006.05.013.

Paterson, J. G., \& Zderad, L. T. (1988). Humanistic nursing. New York: National League for Nursing. 
Berg, Christensen-Scheel and Ingeberg: Forming Life

Perruzza, N., \& Kinsella, E. A. (2010). Creative arts occupations in therapeutic practice: A review of the literature. British Journal of Occupational Therapy, 73(6), 261-268. http://dx.doi.org/10.4276/030802210X12759925468943.

Rappaport. (1987). Individual empowerment is seen as perceived or actual, a form of community participation. Journal of Applied Gerontology, 21(2).

Rød, K. (2012). Interview by Boel Christensen-Scheel. Oslo.

Rønning, R. (2011). New Public Management: feil svar på et viktig spørsmål (S. 289-310). Oslo: Forlag1.

Sauter, W. (2000). The theatrical event: Dynamics of performance and perception. Iowa City: University of Iowa Press.

Standerholen, B. (2009). Interview by Boel Christensen-Scheel. Oslo.

Thesen J., \& Malterud, K., (2001). “Empowerment,” og pasientstyrking - et undervisningsopplegg, Tidsskr Norsk Lægeforening. 121: 1624-8

Tilley, C. Y. (2006). Handbook of material culture. London: SAGE.

Tveiten, S. Haukland, M., \& Flittie Onstad, R. (2011, March). The patient's voice-empowerment in a psychiatric context. Vård i Norden. 20-22.

Ulfrstad L.-M. (2007). Boligpolitikken og velferdsstaten I: Under tak - mellom vegger Perspektiver på boligens betydning i velferdsstaten, Elisabeth Brodkorp Marianne Rugkåsa (Red) Oslo Gyldendal Akademiske.

Varto, J. (2009). Basics of artistic research. Ontological, epistemological and historical justifications. (E. Lehtinen \& L. Mänki, Trans.). Helsinki: University of Art and Design Helsinki.

Ward, J. (2008). The Frog Who Croaked Blue - Synesthesia and mixing of the senses. London: Routledge.

Wibeck, V. (2010). Fokusgrupper: om fokuserade gruppintervjuer som undersökningsmetod, Lund: Studentlitteratur Janecke Thesen og Kirsti Malterud, Tidsskr Norsk Lægeforening, 2001; 121: 1624-8.

Wikström, B.-M., Theorell, T., \& Sandström, S. (1992). Psychophysiological effects of stimulation with pictures of works of art in old age. International Journal of Psychosomatics, 39(4), 7.

Wikström, B.-M., Ekvall, G., \& Sandström, S. (1994). Stimulating the creativity of elderly institutionalized women through works of art. Creativity Research Journal, 7(2). http://dx.doi.org/10.1080/10400419409534522.

White Paper 25 (1996/97). Apenhet og helhet, [Transparency and Coherence] http://www.regjeringen.no/nb/dep/hod/dok/regpubl/stmeld/19961997/st-meld-nr-25_199697.html?id=191086

White Paper 47 (2008-2009). Samhandlingsreformen, http://www.regjeringen.no/pages/2206374/PDFS/STM200820090047000DDDPDFS.pdf

Yin, R. K. (2009). Case study research: Design and methods. Thousand Oaks, CA.: Sage 